\title{
Factors underlying support or opposition to biotechnology among Australian food consumers and implications for retailer-led food regulation
}

\author{
Stewart Lockie ${ }^{\mathrm{a}, *}$, Geoffrey Lawrence ${ }^{\mathrm{b}}$, \\ Kristen Lyons ${ }^{\mathrm{c}}$, Janet Grice ${ }^{\mathrm{b}}$ \\ ${ }^{a}$ Faculty of Arts, Health and Sciences, Centre for Social Science Research, Central Queensland University, \\ Rockhampton, Qld 4702, Australia \\ b School of Social Science, The University of Queensland, Qld, Australia \\ ${ }^{\mathrm{c}}$ School of Science, Griffith University, Australia
}

\begin{abstract}
Despite current findings that consumers, on average, have negative attitudes to biotechnologies such as cloning and genetic engineering, considerable variability can be found in the direction and strength of these attitudes. This paper presents a path analysis of attitudinal, motivational, demographic and behavioural variables that influence consumer dispositions towards biotechnology. Among these variables, those found to be most important were: consumers' level of motivation to find natural foods; the extent to which they were motivated by convenience; whether they did the shopping for their household on a regular basis; and their sex. In terms of direct effects on dispositions to biotechnology, motivation to find natural foods had a very strong negative effect while convenience had a very strong positive effect. Sex had a moderate direct effect with women less likely to be positively disposed towards biotechnology than men. In an apparent contradiction, taking responsibility for household shopping had an equally strong positive effect on both naturalness and convenience. However, sex also played a crucial role here with a very strong effect on motivation to find natural foods
\end{abstract}

\footnotetext{
* Corresponding author. Tel.: +61 7 49306539; fax: +61 749306402.

E-mail address: s.lockie@cqu.edu.au (S. Lockie).
} 
(women more motivated), a minor effect on convenience (women less motivated) and a strong effect on responsibility for household shopping (women more likely to shop). The policy implications of these findings are important, given the apparent oppositional trends of some sections of the food industry to endorse biotechnology, and of the supermarkets to deliver 'clean and green' non-GM foods to consumers.

(C) 2005 Elsevier Ltd. All rights reserved.

Keywords: Biotechnology; Genetic engineering; Consumer attitudes; Natural foods

\section{Introduction}

While biotechnologies such as selective breeding, fermentation and enzyme production have been used for centuries to produce foods and medicines, new biotechnologies such as genetic engineering and cloning that allow direct transfer of genetic material between species, and accelerated reproduction within them, suggest the possibility of more revolutionary change (Norton, 2001). With the benefits of the new biotechnologies considered by proponents to range from reduced environmental damage to improvements in animal welfare, farm productivity, product quality and human health, it seems little wonder that adoption of such technologies by farmers and by food companies has been rapid. By 2003, an estimated 68 million hectares of land worldwide - or 25 percent of the total cropped area - was sown to GM crops (Pew Initiative on Food and Biotechnology, 2004). This represented a nearly 40 -fold increase over the area planted to GM crops in 1996 (Pew Initiative on Food and Biotechnology, 2004). The enthusiasm of consumers to purchase and feed themselves and their families transgenic produce has, however, been rather more muted.

A great many studies from around the world have demonstrated considerable reluctance among consumers to embrace the new biotechnologies (INRA, 1991, 2000; Decima Research, 1993; Lemkow, 1993; Florkowski et al., 1994; Frewer and Shepherd, 1995; Norton, 1999; Marris et al., 2001; Grice and Lawrence, 2003). These studies suggest that concern is greatest in relation to products that are destined for human ingestion, that offer no tangible benefits to the consumer, and that are applied to animals. By contrast, the use of the new biotechnologies to produce novel medicines and to enhance production of fibre and ornamental plants is rather less controversial. Contrary to claims by biotech proponents that resistance to genetic engineering is based on ignorance, a number of studies have shown that the more people know about biotechnologically derived foods the more likely they are, in fact, to reject them (see discussions in Lawrence et al., 2001 and Grice and Lawrence, 2003). Overall, women are more opposed to application of the new biotechnologies than are men (Norton, 1999).

Unlike the work of those involved in the above studies, we are not concerned here with determining the level of consumer support or opposition to biotechnologies, nor, the types of biotechnological applications to which they are more or less averse. Rather, we are concerned with exploring how a range of attitudinal, motivational, behavioural, and demographic variables interact to influence 
consumers' overall dispositions towards biotechnology and the implications of these findings for food policy. The paper attempts, therefore, to identify the key values and attributes that are likely to underlie choices made by Australian consumers about novel foods irrespective of the characteristics and claims of specific biotechnology applications. To this end, over 1200 Australian consumers were surveyed on their attitudes to biotechnology; the motivations that affected their food choices in general (using the scales developed by Steptoe et al. (1995) and Lindeman and Väänänen (2000)); and their involvement in so-called green consumption activities such as recycling. Before turning to the survey we will explore briefly the policy and regulatory context in which consumption of biotech foods must be located.

\section{The governance of food biotechnologies}

Some policy analysts have argued that the regulation of the new biotechnologies might more adequately be described as regulation for industry than as regulation of industry (Newell, 2001). While genetic engineering and other biotechnologies are subject to a plethora of legal regulations, non-legal rules and codes, international conventions and so on (Black, 1998), the over-riding principles behind these are the inter-related concepts of 'risk management' and 'substantial equivalence' (Levidow and Carr, 2000; Newell, 2002). Under this regime, where genetically modified foods are determined to have similar physical and chemical properties as conventional foods they are deemed suitable for treatment in the same manner with regard to health and safety and subjected to little, if any, additional testing. This facilitates rapid approval of genetically modified foods by shifting the onus of responsibility away from the biotechnology industry to establish the safety of such foods and onto its opponents to establish their riskiness (Levidow and Carr, 2000). Further, questions regarding the purpose and social implications of genetic engineering are ruled out as legitimate concerns and the public accorded little role beyond the choices they may make as consumers within food markets (Black, 1998; Levidow and Tait, 1995; Newell, 2002).

None of this is to suggest that the risk management regime is interpreted and applied uniformly across national boundaries, nor that it has not been subject to considerable contestation and debate. Moves, for example, by the European Union to introduce the 'precautionary principle' by extending risk assessment to cover the entire food production process and introducing stricter labelling of genetically modified foods (FSA, 2003) have been criticised by the US and others as non-tariff barriers to trade that are not based on 'sound science' (Levidow and Carr, 2000). At the same time, social movements opposed to genetic engineering on a range of grounds have won a series of concessions from regulatory agencies and biotech firms alike (Tokar, 2001). However, arguably the most significant challenge to continued expansion of the new food biotechnologies lies in the increasing role of large retailers in private sector regulation of food production, processing and distribution (Marsden et al., 2000). 
Marsden et al. (2000) argue that a key feature of retailer-led food industry selfregulation is likely to be the imposition of progressively more stringent food quality standards designed both to enhance positive food attributes and to avoid food 'hazards'. While there can be little doubt that much of the motivation for food quality standards and associated quality assurance regimes lies in the minimisation of liability for food-borne hazards (Pearce and Hansson, 2000), such standards also provide retailers with opportunities to represent themselves as champions of consumer interest and demands (Lockie, 2002). At the same time, therefore, that self-regulatory regimes based on risk minimisation have been promoted by the food biotech industries as strategies to ensure their own growth, application of the same principles by retailers may have very different results. Understanding better the basis of food consumer dispositions towards the new biotechnologies is thus of as much relevance to the future of self-regulatory practices in the food industry as it is to democratic institutions and social movement politics.

\section{Methodology}

\section{Sampling and survey design}

The study was undertaken in three stages. First, 13 focus group interviews were conducted to identify those issues of concern to consumers and to assist later in survey data interpretation. To ensure a degree of representativeness the groups were conducted in both metropolitan and regional centres in Queensland and Victoria and with a variety of socio-economic and ethnic groups.

Second, a preliminary set of questions on attitudes related to food was developed and pre-tested with 77 students from Central Queensland and Griffith Universities. Scales were then developed for the issues of primary concern; namely, disposition towards biotechnologies; perceived risks from industrial food production and processing methods such as chemical use, irradiation, artificial additives and genetic engineering; attitudes towards certified organic foods; and willingness to pay more for food that has been produced in an environmentally friendly manner. The scale on risks from industrialised foods included five four-point items taking the form: "How high would you consider the risk posed to food consumers by regular consumption of foods grown or treated with pesticides and other chemicals?" where $1=$ very low risk and $4=$ very high risk. The remaining scales comprised 19 five-point items taking the form: "How strongly do you agree or disagree with the statement, scientists are going too far with cloning and other biotechnologies?" where $1=$ strongly disagree and $5=$ strongly agree. Each scale was tested for validity following the survey and four items deleted. The final attitudinal scales are shown in Table 1 .

Third, 1212 Australian consumers were surveyed using computer-assisted telephone interviewing facilities at the Centre for Social Science Research, Central Queensland University. The target population designated for telephone interviewing was all persons 18 years of age or older who, at the time of the survey, were living in 
Table 1

Attitudinal scales

\begin{tabular}{|c|c|c|c|c|}
\hline Scale & Item & $\begin{array}{l}\text { Mean item } \\
\text { score }^{\mathrm{a}}\end{array}$ & $\begin{array}{l}\text { Standard } \\
\text { deviation }\end{array}$ & $\begin{array}{l}\text { Scale reliability } \\
{\text { (Cronbach's alpha })^{b}}^{\text {Cron }}\end{array}$ \\
\hline \multirow[t]{4}{*}{ Disposition towards biotechnology } & Scientists are going too far with cloning and other biotechnologies & 2.21 & 1.307 & \multirow[t]{4}{*}{0.63} \\
\hline & $\begin{array}{l}\text { Biotechnologies like cloning and genetic engineering are against the } \\
\text { laws of nature }\end{array}$ & 2.53 & 1.368 & \\
\hline & $\begin{array}{l}\text { Releasing genetically modified organisms into the environment is } \\
\text { too risky. We just don't know what will happen }\end{array}$ & 2.18 & 1.352 & \\
\hline & $\begin{array}{l}\text { All foods containing genetically modified ingredients should be } \\
\text { labelled so that consumers can make their own choice }\end{array}$ & 1.61 & 0.833 & \\
\hline \multirow[t]{5}{*}{ Risks from industrialised foods } & Pesticides and other chemicals & 1.91 & 0.992 & \multirow[t]{5}{*}{0.74} \\
\hline & Genetically modified organisms & 2.38 & 1.388 & \\
\hline & Food irradiation & 1.98 & 1.266 & \\
\hline & Preservatives and artificial colouring & 2.41 & 0.927 & \\
\hline & Hormones and antibiotics in meat & 1.98 & 1.091 & \\
\hline \multirow[t]{4}{*}{ Healthiness of organic foods } & $\begin{array}{l}\text { Organic foods have lower chemical residues than conventional } \\
\text { foods }\end{array}$ & 2.52 & 1.551 & \multirow[t]{4}{*}{0.72} \\
\hline & $\begin{array}{l}\text { Organic foods have no more vitamins and minerals than } \\
\text { conventional foods }\end{array}$ & 3.87 & 1.417 & \\
\hline & Organic foods are safer to eat than conventional foods & 2.69 & 1.404 & \\
\hline & Organic food is healthier to eat than conventionally grown food & 2.69 & 1.400 & \\
\hline \multirow[t]{3}{*}{ Quality of organic foods } & Organic food tastes better than conventional food & 3.13 & 1.553 & \multirow[t]{3}{*}{0.56} \\
\hline & Organic food looks inferior to conventional food & 3.50 & 1.312 & \\
\hline & Organic food has a shortened shelf life & 3.37 & 1.705 & \\
\hline \multirow[t]{2}{*}{$\begin{array}{l}\text { Fairness of premium for } \\
\text { environment-friendly food }\end{array}$} & $\begin{array}{l}\text { The prices received by Australian farmers are not high enough for } \\
\text { them to address environmental problems }\end{array}$ & 2.60 & 1.570 & \multirow[t]{2}{*}{0.70} \\
\hline & I think it is fair to pay farmers more for producing food in an & 2.13 & 0.968 & \\
\hline
\end{tabular}


Table 1 (continued)

\begin{tabular}{|c|c|c|c|c|}
\hline Scale & Item & $\begin{array}{l}\text { Mean item } \\
\text { score }^{\mathrm{a}}\end{array}$ & $\begin{array}{l}\text { Standard } \\
\text { deviation }\end{array}$ & $\begin{array}{l}\text { Scale reliability } \\
\text { (Cronbach's alpha) }^{\text {b }}\end{array}$ \\
\hline \multirow{2}{*}{$\begin{array}{l}\text { Willingness to buy more } \\
\text { organic food if available }\end{array}$} & I would gladly buy more organic food if I could find it & 2.59 & 1.212 & \multirow[t]{2}{*}{0.64} \\
\hline & $\begin{array}{l}\text { I would buy more organic food if it was available as convenience, } \\
\text { packaged and pre-prepared food }\end{array}$ & 2.86 & 1.235 & \\
\hline \multirow[t]{5}{*}{ Environmental behaviours } & $\begin{array}{l}\text { How often do you recycle paper, glass and other household waste } \\
\text { products? }\end{array}$ & 1.47 & 0.953 & \multirow[t]{5}{*}{0.32} \\
\hline & $\begin{array}{l}\text { How often do you purchase environmentally friendly cleaning } \\
\text { products such as phosphate-free laundry powder or detergent? }\end{array}$ & 2.80 & 1.279 & \\
\hline & How often do you compost your food scraps at home? & 2.51 & 1.430 & \\
\hline & $\begin{array}{l}\text { Are you a member, or do you participate, in an environmental } \\
\text { organisation (such as Landcare, Greenpeace, the Wilderness } \\
\text { Society, a local community group)? }\end{array}$ & 1.86 & 0.358 & \\
\hline & $\begin{array}{l}\text { Have you ever written a letter or made a phone call to a member of } \\
\text { parliament, government department or your local council on an } \\
\text { environmental matter? }\end{array}$ & 1.77 & 0.423 & \\
\hline
\end{tabular}

${ }^{a}$ Risks from industrialised foods based on four point scale where $1=$ very high risk and $4=$ very low risk. All other variables based on five point scale where $1=$ strongly agree and $5=$ strongly disagree.

${ }^{\text {b }}$ Cronbach's alpha is a statistic used to test the reliability of a multi-item scale by measuring the average inter-item correlation. High values (between 0.5 and $1.0)$ indicate a satisfactory scale. 
a dwelling unit anywhere in Australia that could be contacted by a direct-dialled, land-based telephone service. A random selection approach was used to ensure that all potential participants had an equal chance of being contacted. The survey itself was designed to gather data on: motivational factors such as environmental and health concerns likely to influence food choice; attitudes towards contemporary food-related issues such as food safety, biotechnology and organics; and demographic characteristics.

Items on motivations affecting food consumption were drawn from Steptoe et al.'s (1995) food choice questionnaire with the addition of Lindeman and Väänänen's (2000) expanded range of items on ethical food choice motives. This instrument is designed to provide a multidimensional measure of motives related to food choice including health, weight control, ethical concerns, familiarity, sensory appeal, mood, convenience, natural content and price. Minor changes were made to the wording of several questions to reflect terminology with which Australian consumers were more likely to be familiar and two items added were directed more specifically to physical fitness. Each item took the form: "how important is it to you that the food you eat on a typical day contains a lot of vitamins and minerals?" Table 2 shows the scales, items and scale reliability.

\section{Data analysis procedures}

The factors behind food choice are too complex to be explained with a single motivation, attitude or other variable. Path analysis is thus used here as a multivariate tool to illustrate proposed causal relationships between multiple variables (De Vaus, 1991). Path analysis requires the prior construction of a path diagram based on theoretical reasoning. The path diagram consists of variables and the possible relationships between them. Relationships are denoted by directional arrows with the causal variable at the base of the arrow and the dependent variable at the arrowhead. Each variable may have an effect on several other variables and direct and indirect effects also are possible. Thus sex could influence an attitude directly or indirectly through an intervening variable such as education. While the idea of causality may be controversial (Mueller, 1996), path analysis provides a way of determining the inter-relationships of multiple variables in determining a particular outcome. The path diagram gives a pictorial representation of this relationship. Analysis of the path diagram produces the values of the path coefficients (the standardised partial regression coefficients). The path coefficients are "interpreted as absolute measures of direct causal influence" (Kotz et al., 1982, p. 636). The total causal effect of any variable on another variable may be calculated using the path coefficients. The direct effect of one variable on another is equal to the path coefficient. The indirect effect is calculated by multiplying the path coefficients along the desired path. The total effect is the sum of the direct and indirect effects (De Vaus, 1991).

Steptoe et al. (1995) note that while the scales developed in their food choice questionnaire have high internal reliability there are also strong enough correlations 
Table 2

Food choice scales

\begin{tabular}{|c|c|c|c|c|}
\hline Scale & $\begin{array}{l}\text { Item How important is it to you that the food you eat on a } \\
\text { typical day ...? }\end{array}$ & $\begin{array}{l}\text { Mean item } \\
\text { score }\end{array}$ & $\begin{array}{l}\text { Standard } \\
\text { deviation }\end{array}$ & $\begin{array}{l}\text { Scale reliability } \\
\text { (Cronbach's alpha) }\end{array}$ \\
\hline Health & $\begin{array}{l}\text { Contains a lot of vitamins and minerals } \\
\text { Keeps you healthy } \\
\text { Is nutritious } \\
\text { Is high in protein } \\
\text { Is good for your skin/teeth/hair/nails, etc. } \\
\text { Is high in fibre and roughage }\end{array}$ & $\begin{array}{l}4.08 \\
4.44 \\
4.43 \\
3.39 \\
3.66 \\
3.89\end{array}$ & $\begin{array}{l}1.034 \\
0.841 \\
0.870 \\
1.225 \\
1.336 \\
1.078\end{array}$ & 0.82 \\
\hline Weight control & $\begin{array}{l}\text { Is low in calories } \\
\text { Helps you control your weight } \\
\text { Is low in fat }\end{array}$ & $\begin{array}{l}3.20 \\
3.27 \\
3.81\end{array}$ & $\begin{array}{l}1.307 \\
1.403 \\
1.248\end{array}$ & 0.84 \\
\hline Fitness & $\begin{array}{l}\text { Provides enough energy to get through your physical } \\
\text { exercise program } \\
\text { Does not compromise your sporting and exercise goals }\end{array}$ & $\begin{array}{l}3.69 \\
2.58\end{array}$ & $\begin{array}{l}1.308 \\
1.460\end{array}$ & 0.54 \\
\hline Mood & $\begin{array}{l}\text { Helps you cope with stress } \\
\text { Helps you relax } \\
\text { Keeps you awake/alert } \\
\text { Cheers you up } \\
\text { Makes you feel good }\end{array}$ & $\begin{array}{l}2.56 \\
2.88 \\
2.38 \\
2.87 \\
3.83\end{array}$ & $\begin{array}{l}1.507 \\
1.407 \\
1.442 \\
1.479 \\
1.218\end{array}$ & 0.80 \\
\hline Convenience & $\begin{array}{l}\text { Is quick and easy to prepare } \\
\text { Can be cooked very simply } \\
\text { Can be bought in shops close to where you live } \\
\text { Is easily available in shops and supermarkets } \\
\text { Is not messy to eat }\end{array}$ & $\begin{array}{l}3.82 \\
4.01 \\
3.82 \\
4.23 \\
2.93\end{array}$ & $\begin{array}{l}1.102 \\
1.095 \\
1.341 \\
0.980 \\
1.423\end{array}$ & 0.73 \\
\hline Sensory appeal & $\begin{array}{l}\text { Smells nice } \\
\text { Looks nice } \\
\text { Has a pleasant texture }\end{array}$ & $\begin{array}{l}4.13 \\
3.53 \\
3.66\end{array}$ & $\begin{array}{l}0.998 \\
1.215 \\
1.180\end{array}$ & 0.67 \\
\hline
\end{tabular}




\begin{tabular}{|c|c|c|c|c|}
\hline Natural content & Contains no additives & 3.61 & 1.234 & 0.86 \\
\hline & Contains natural ingredients & 4.19 & 0.994 & \\
\hline & Contains no artificial ingredients & 3.62 & 1.207 & \\
\hline & Certified free of chemical and hormone residues & 3.63 & 1.413 & \\
\hline & Is as unprocessed as possible & 3.73 & 1.206 & \\
\hline & Is prepared in a way that preserves its natural goodness & 4.29 & 0.873 & \\
\hline Price & Is not expensive & 3.53 & 1.174 & 0.58 \\
\hline & Is good value for money & 4.33 & 0.825 & \\
\hline Familiarity & Is what you usually eat & 3.63 & 1.128 & 0.61 \\
\hline & Is familiar & 3.44 & 1.240 & \\
\hline & Is like the food you ate when you were a child & 2.59 & 1.380 & \\
\hline Animal welfare & $\begin{array}{l}\text { Has been produced in a ways that animals have not } \\
\text { experienced pain }\end{array}$ & 3.59 & 1.425 & 0.86 \\
\hline & $\begin{array}{l}\text { Has been produced in a way that animals' rights have } \\
\text { been respected }\end{array}$ & 3.64 & 1.375 & \\
\hline Environmental protection & Is prepared in an environmentally friendly way & 3.78 & 1.237 & 0.79 \\
\hline & $\begin{array}{l}\text { Is produced in a way that has not shaken the balance } \\
\text { of nature }\end{array}$ & 3.47 & 1.372 & \\
\hline & Is packaged in an environmentally friendly way & 3.18 & 1.360 & \\
\hline & Is grown locally to reduce transportation & 3.42 & 1.380 & \\
\hline Political values & Comes from a country that you approve of politically & 2.99 & 1.603 & 0.78 \\
\hline & Comes from a country in which human rights are respected & 2.90 & 1.598 & \\
\hline & Has the country of origin clearly marked & 3.80 & 1.370 & \\
\hline & $\begin{array}{l}\text { Has been prepared in a way that does not conflict with } \\
\text { your political values }\end{array}$ & 2.46 & 1.497 & \\
\hline Religion & Is not forbidden by your religion & 1.59 & 1.217 & \\
\hline & Is in harmony with your religious views & 1.50 & 1.133 & 0.66 \\
\hline
\end{tabular}


between a number of the scales to suggest that collapsing them into a smaller number of factors may be appropriate. While Steptoe et al. (1995) justify the maintenance of the full nine scales on the basis that investigating a wide range of specific motives of food choice is likely to be more useful than assessment of a small number of broad dimensions, the use here of path analysis to describe the causal relationships between multiple variables necessitated assimilation of scale items into the smallest number of variables practicable. Factor analysis was, therefore, conducted prior to undertaking the path analysis and a revised set of scales developed. Factor analysis is a statistical technique used to describe data using a smaller set of underlying variables (De Vaus, 1991).

\section{Results}

The attitudes of consumers towards biotechnologies were, on average, more negative than positive (see Table 1). Similarly, consumers were generally concerned about the long term riskiness of industrialised food production and processing techniques (see Table 1) and professed to be highly motivated by the health, naturalness, animal welfare and environmental attributes of foods. However, there also were considerable levels of variability in the direction and strength of consumer attitudes and motivations towards a number of scales including disposition towards biotechnology. While the broad thrust of community opinion would appear to be cautious regarding biotechnology, enough variability was evident to suggest that underlying food choice motives and behaviours may have some ability to account for differing levels of opposition and support for biotechnologies.

Factor analysis of all items included in Tables 1 and 2 resulted in assimilation of these items into seven underlying factors that explained a large amount of the variance, had good reliability analysis and could sensibly be interpreted. These underlying factors included green consumption behaviours, willingness to pay a premium for environmental values, convenience, sensory and emotional appeal, natural foods, political and ecological values, healthy food values, and acceptance of biotechnology (see Table 3).

These factors, together with the demographic variables age, sex, income and education level, as well as responsibility for household shopping, were used to conduct a path analysis predicting acceptance of biotechnology. The resultant path can be seen in Fig. 1. The path coefficients are shown in Table 4. The green consumption behaviours and willingness to pay a premium scales did not have a significant impact on acceptance of biotechnology and were removed from the resultant analysis. All other variables were significant at the $95 \%$ confidence level. Further examination showed that the coefficients related to healthy food values were contradictory to the intuitive relationships between healthy food values and education and with other observed relationships between these variables, gender and acceptance of biotechnology. This factor consequently was deleted from the analysis. 
Table 3

Revised scales - motives, attitudes, beliefs and behaviours affecting food choice

\begin{tabular}{llll}
\hline Scale & Abbreviated questions & $\begin{array}{l}\text { Reliability } \\
\text { (Cronbach's alpha) }\end{array}$ & Coding \\
\hline Green consumption behaviours & $\begin{array}{l}\text { Recycling of paper, etc. } \\
\text { Purchase of environmentally friendly cleaning products } \\
\text { Composting food scraps }\end{array}$ & 0.26 & $\begin{array}{l}\text { Amount of recycling decreases as } \\
\text { value increases }\end{array}$
\end{tabular}

Willingness to pay premium

Prices received by farmers not high enough

Agreement decreases as value increases

Convenience

Fair to pay farmers more

Can be bought in shops close to where you live

Importance increases as value increases

Can be cooked very simply

Is easily available in shops and supermarkets

Is not messy to eat

Is quick and easy to prepare

Sensory and emotional appeal Looks nice

Helps cope with stress

Keeps you awake/alert

Cheers you up

Has a pleasant texture

Helps relax

Is adventurous and varied

Is familiar

Tastes good

Is like the food eaten as a child

Smells nice

Makes you feel good

Is what you usually eat

Natural foods

Contains natural ingredients

Contains no additives

Is as unprocessed as possible

Certified free of chemical and hormone residues

Is prepared in a way that preserves its natural goodness

Contains no artificial ingredients

Importance increases as value increases 


\begin{tabular}{|c|c|c|c|}
\hline Scale & Abbreviated questions & $\begin{array}{l}\text { Reliability } \\
\text { (Cronbach's alpha) }\end{array}$ & Coding \\
\hline & $\begin{array}{l}\text { Risk from pesticides and other chemicals } \\
\text { Risk from genetically modified organisms } \\
\text { Risk from food irradiation } \\
\text { Risk from preservatives and artificial colouring } \\
\text { Risk from hormones and antibiotics in meat }\end{array}$ & & \\
\hline Political and ecological values & $\begin{array}{l}\text { Is packaged in an environmentally friendly way } \\
\text { Comes from a country that you approve of } \\
\text { Comes from a country in which human rights not violated } \\
\text { Is grown and manufactured in Australia } \\
\text { Animals' rights have been respected } \\
\text { Prepared in an environmentally friendly way } \\
\text { Is grown locally to reduce transportation } \\
\text { Animals have not experienced pain } \\
\text { Has the country of origin clearly marked } \\
\text { Has not shaken the balance of nature } \\
\text { Does not conflict with political values }\end{array}$ & 0.90 & Importance increases as value increases \\
\hline Healthy Food Values & $\begin{array}{l}\text { Is nutritious } \\
\text { Is low in calories } \\
\text { Helps control weight } \\
\text { Is low in fat } \\
\text { Sporting and exercise goals } \\
\text { Is high in protein } \\
\text { Keeps you healthy } \\
\text { Is high in fibre and roughage } \\
\text { Provides enough energy } \\
\text { Contains a lot of vitamins and minerals } \\
\text { Is good for skin, etc. }\end{array}$ & 0.85 & Importance increases as value increases \\
\hline Acceptance of Biotechnology & $\begin{array}{l}\text { Foods containing GMOs should be labelled } \\
\text { Release GMOs too risky } \\
\text { Scientists going too far } \\
\text { Cloning etc against laws of nature }\end{array}$ & 0.70 & Agreement decreases as value increases \\
\hline
\end{tabular}

Risk from pesticides and other chemicals

Risk from preservatives and artificial colourin

Is packaged in an environmentally friendly way

Comes from a country that you approve of

Comes from a country in which human rights not violated

Prepared in an environmentally friendly way

grown locally to reduce transportation

Reliability 


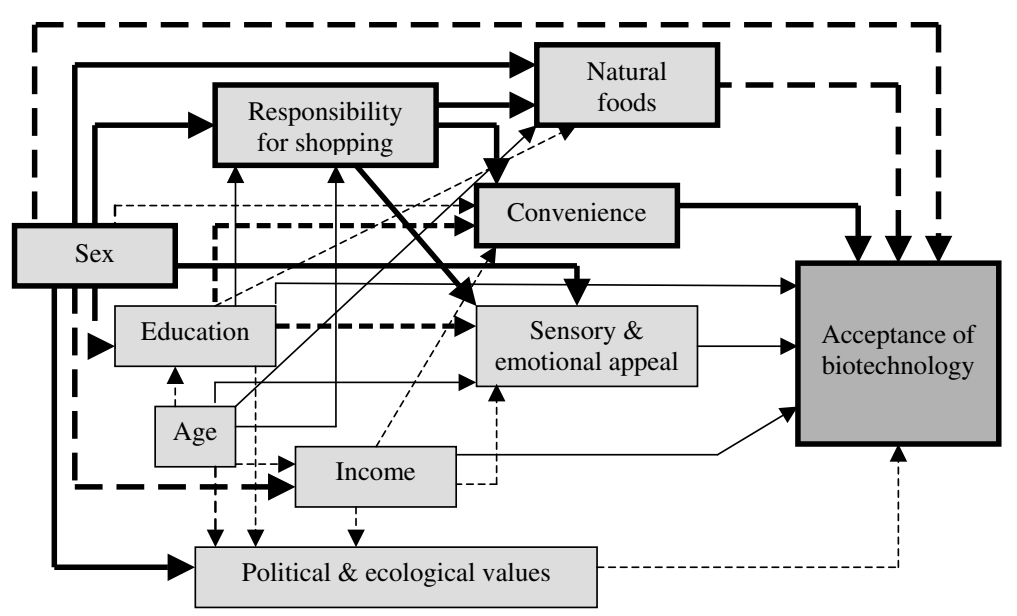

Key:

Major positive effect $(>0.20$ in magnitude)

Major negative effect $(>0.20$ in magnitude)

Medium positive effect $(0.10-0.19$ in magnitude $)$

Medium negative effect $(0.10-0.19$ in magnitude $)$

Minor positive effect $(<0.10$ in magnitude)

Minor negative effect $(<0.10$ in magnitude $)$

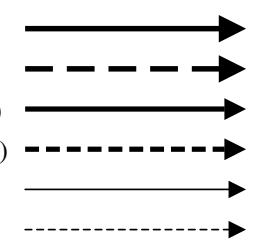

Note: a positive relationship in relation to sex indicates higher scores among women than men.

Fig. 1. Path model for increasingly positive disposition towards biotechnology.

\section{Discussion}

Of the eight variables significantly associated with consumers' acceptance of biotechnology, natural foods and convenience had by far the largest effects. These effects were, however, in opposite directions, with those consumers motivated to find foods they considered natural being least favourable towards biotechnology, and those consumers interested more in convenience being most favourable. Sex also contributed a moderate effect, with women less favourably disposed towards biotechnology than men.

The negative association between natural foods and acceptance of biotechnology is not surprising in light of several items included in the natural foods scale. The inclusion of items relating to the perceived riskiness of ingesting genetically modified foods and the benefits, in contrast, of organic foods, clearly establishes a logical inconsistency between concern for naturalness and support for biotechnology. However, in interpreting this seemingly inevitable result it is important to remember that the natural foods scale was a new variable based on factor analysis that revealed a high level of correlation between the general items on naturalness included in 
Table 4

Path analysis - value of effects

\begin{tabular}{|c|c|c|}
\hline Variable 1 & Variable 2 & Value of effect \\
\hline Acceptance of biotechnology & $\begin{array}{l}\text { Natural foods } \\
\text { Convenience } \\
\text { Sex } \\
\text { Education } \\
\text { Health } \\
\text { Sensory and emotional appeal } \\
\text { Political and ecological values } \\
\text { Income }\end{array}$ & $\begin{array}{r}-0.48 \\
0.44 \\
-0.22 \\
0.09 \\
0.07 \\
0.06 \\
-0.04 \\
0.01\end{array}$ \\
\hline Natural foods & $\begin{array}{l}\text { Sex } \\
\text { Responsibility for shopping } \\
\text { Education } \\
\text { Age }\end{array}$ & $\begin{array}{r}0.45 \\
0.22 \\
-0.05 \\
0.02\end{array}$ \\
\hline Convenience & $\begin{array}{l}\text { Responsibility for shopping } \\
\text { Education } \\
\text { Sex } \\
\text { Income }\end{array}$ & $\begin{array}{r}0.27 \\
-0.12 \\
-0.09 \\
-0.02\end{array}$ \\
\hline Responsibility for shopping & $\begin{array}{l}\text { Sex } \\
\text { Education } \\
\text { Age }\end{array}$ & $\begin{array}{r}0.32 \\
0.01 \\
>0.01\end{array}$ \\
\hline Sensory and emotional appeal & $\begin{array}{l}\text { Sex } \\
\text { Responsibility for shopping } \\
\text { Education } \\
\text { Income } \\
\text { Age }\end{array}$ & $\begin{array}{r}0.30 \\
0.22 \\
-0.10 \\
-0.02 \\
0.01\end{array}$ \\
\hline Political and ecological values & $\begin{array}{l}\text { Sex } \\
\text { Education } \\
\text { Income } \\
\text { Age }\end{array}$ & $\begin{array}{r}0.44 \\
-0.05 \\
-0.02 \\
0.01\end{array}$ \\
\hline Education & $\begin{array}{l}\text { Sex } \\
\text { Age }\end{array}$ & $\begin{array}{l}-0.29 \\
-0.02\end{array}$ \\
\hline Health & $\begin{array}{l}\text { Sex } \\
\text { Education } \\
\text { Age }\end{array}$ & $\begin{array}{r}0.49 \\
-0.04 \\
0.02\end{array}$ \\
\hline Income & $\begin{array}{l}\text { Sex } \\
\text { Age }\end{array}$ & $\begin{array}{l}-1.11 \\
-0.05\end{array}$ \\
\hline
\end{tabular}

Steptoe et al.'s (1995) natural content scale and additional items developed to assess more specifically the perceived riskiness of industrialised foods, and so on. While the survey, in other words, made no presuppositions about the naturalness or otherwise of food biotechnologies, respondents very clearly signalled their belief that food biotechnologies were not natural. The arguments of biotechnology proponents that new technologies such as genetic engineering are natural extensions of age-old selective breeding practices - and the resultant products functionally equivalent to conventional 
foods - had not convinced the majority of food consumers. As a consequence, those consumers who were more supportive of biotechnology tended to be those who were less motivated to avoid foods that were processed or contained artificial additives, less likely to believe that industrial food technologies such as agri-chemicals and food irradiation posed significant threats, and less likely to believe that organic foods offered consumers greater safety, quality or nutrition. As Tables 1 and 2 show, such consumers were comparatively few in number.

Those consumers who were more positively disposed towards biotechnology were also considerably more motivated to base their food choices on convenience; that is, on foods that are quick and easy both to purchase and to prepare. This result is consistent with outcomes of the consumer focus groups, which found a perceived lack of convenience to be a major barrier to increased consumption of certified organic foods even among those who considered the 'naturalness' of organic foods a distinct advantage (see Lyons et al., 2001; Lockie et al., 2002).

While high levels of motivation towards natural foods and convenience produced contradictory effects on disposition towards biotechnology, both were influenced in turn to an equally strong positive degree by whether or not consumers undertook household shopping on a regular basis. Taking responsibility for household food provisioning may be seen logically to influence levels of motivation towards both natural foods and convenience on the basis that those taking such responsibility are confronted with the additional responsibility of ensuring household members are provided with foods that are safe and nutritious, and with the burden on their time and energy that comes with such responsibility. Forced into confronting the implications of their choices for themselves and others, those who take responsibility for food provisioning express stronger views on the importance of both naturalness and convenience than do those who are fed by others. The question that remains is how taking responsibility for shopping can lead, it seems, to both positive and negative effects on consumers' dispositions towards biotechnology through the intervening variables natural foods and convenience. The critical point here is that while responsibility for shopping had a strong effect on both natural foods and convenience it was not the only variable exerting an influence and did not itself have a significant direct relationship on acceptance of biotechnology.

The largest effect on motivation towards natural foods came not from responsibility for shopping but from sex, with women considerably more likely to be motivated towards natural foods than were men. Consistent with this result, women were slightly less likely than men to be motivated by convenience despite being considerably more likely to take responsibility for household shopping on a regular basis. Further, women had lower levels of education than men with education, in turn, having a moderate negative effect on motivation towards convenience. Taking all this into account, the effect of sex on acceptance of biotechnology both directly and through the intervening variables natural foods and convenience best accounts for the seemingly contradictory impact of responsibility for shopping.

It is worth noting that sex had a major effect on all variables except for age, with women showing consistently less positive attitudes towards biotechnologies and 
other industrialised food production and processing technologies conceived as unnatural and risky. Women also were considerably more motivated than men to consume foods they regarded as consistent with their political and ecological values and foods that offered sensory and emotional appeal. In fact, the only food-related value towards which women were less motivated than men was convenience. These gender differences were explained by several focus group participants as the outcome of women's traditionally care-oriented roles within the household, an explanation echoed in a range of other studies (see Cunningham, 2001). The results here, however, do not support this explanation. The effect of responsibility for shopping on acceptance of biotechnology was no greater in magnitude than a range of other variables, indirect and, most importantly, contradictory. In fact, taking responsibility for shopping was just as likely to lead to an acceptance of biotechnology (through the intervening variable of convenience) as it was to its rejection (through the intervening variable of natural foods). As the path diagram shows, women both were more likely than men to be directly motivated to consume foods they considered natural and to reject biotechnology outright.

A further question remains regarding why the remaining variables had little, if any, effect on dispositions towards biotechnology. Of most interest in this regard are those variables related to values since there is no a priori reason to suspect that the remaining demographic variables would have substantial effects. Given the importance of natural foods, in particular, it would be reasonable to speculate that other health and environmental values would also have major effects. The most convincing explanation, we believe, for why they did not lies in the confusion and ambivalence many consumers express towards the environmental and health attributes of biotechnology (see Lockie et al., 2002). Focus group participants were aware, for example, of claims by biotechnology proponents that technologies such as genetic engineering offered opportunities to improve the environmental sustainability of food production while developing foods that were more nutritious, tasted better and/or contained medicinal compounds. They were also aware of the criticisms made by biotechnology proponents of alternative production systems such as organic agriculture, which they charged with depleting soil reserves and lowering food production in an era of rapid population growth. Despite the scepticism of many focus group participants regarding these claims, consumers were clearly faced with an environment in which competing knowledge claims regarding biotechnology may reasonably have led them to a range of conclusions regarding its advantages and disadvantages.

\section{Implications for food governance}

State regulation of the new biotechnologies predominantly has been based on scientifically defined notions of 'risk management' and 'substantial equivalence'. Criticisms of this regime have focussed on what is perceived as an undemocratic bias towards narrow sectoral interests; a myopia towards indeterminable ecological and health risks; and a failure to learn the lessons of earlier food scares and the 
erosion of trust in regulatory and scientific institutions to which they have contributed (Schweiger, 2001; Tokar, 2001). Underlying this, according to Barling et al. (2002); Lang et al. (2001) and Murcott (1999), has been a dominance of productivist concerns within food policy more generally and an ensuing lack of institutional and legislative integration between the goals of food production, public health and natural resource management. Within this context, calls to establish public debate and participation in decision-making as the touchstone of new policy about food regulation and safety make considerable sense (see Murcott, 1999). They are consistent also with the finding here that despite the many millions of dollars spent by industry and governments on public relations campaigns designed to promote the merits of the new biotechnologies (Hindmarsh and Lawrence, 2001), food consumers remain, on the whole, sceptical. However, it is important to note that statebased legislative processes are not the only arenas through which biotechnologies are governed.

New regulatory regimes are emerging due, in large part, to the increasingly influential role of large retailers in the food industry (Marsden et al., 2000). A clear pattern has become evident in Australia, the UK and elsewhere, of pre-emptive moves on the part of large supermarket chains to impose quality assurance schemes that exceed legislative requirements for labelling, food safety and so on (Lockie and Salem, 2005; Pearce and Hansson, 2000). These may be seen as part of a broader strategy to foster consumer trust, reduce exposure to food-borne risks and minimise liability (Pearce and Hansson, 2000) that potentially stands supermarkets in stark contrast with the pro-biotech orientation of the food production and processing industries (Goodman and Redclift, 1991; Weeks, 1999). Indeed, some of the world's largest retailing chains have taken steps to eliminate genetically modified foods from their own-brand products and to make organic and other certified GE-free foods more widely available (Burch et al., 2001; Tokar, 2001). It would be naïve to suggest that these steps have been simply out of response to consumer 'demands'. It would be equally naïve to suggest that reluctance to stock GE products either is universal across the retailing sector (see Schweiger, 2001) or that it is not likely to be challenged. Nevertheless, in a legislative environment in which the public is accorded little role beyond the choices they may make as consumers (see above), the opportunities opened up for the expression of consumer and social movement agency by retailer-led regulatory regimes are interesting and important.

As this study shows, few Australian consumers consider foods produced using biotechnologies such as genetic engineering to be natural and many reject them on that basis. While taking responsibility for household food provisioning itself produces contradictory effects, it is telling that women, who are overwhelmingly responsible for shopping and food preparation, are also overwhelmingly convinced that biotech foods are not natural. For retailers - the primary point of contact between food consumers and the food industry - there seem to be three broad ways in which they may respond to these concerns. The first, echoing the approach promoted by the biotech sector, is to continue to promote 'risk management' and 'substantial equivalence'; that is, to cooperate with existing legislative requirements that effectively hide the GE status of foods through minimal, if any, labelling. The second, is to seek to eliminate all 
GE foods by stocking only those that can be certified GE-free using reliable audit procedures. The third, and perhaps most likely, is a compromise whereby genetically engineered and other biotech foods sit alongside organic (or other 'natural') foods on supermarket shelves. Whichever of these option individual retailers pursue, it can be taken more-or-less as given that their own regulatory activities - including the use of third party certified quality assurance systems - will continue to expand. The challenge for retailers will lie in aligning these essentially bureaucratic procedures with notions of food 'quality', such as 'naturalness', that are not easily defined. While the items comprising the natural foods scale used in this research provide a negative definition (i.e. natural foods are those that are not processed, irradiated and so on), it is rather more difficult for the majority of consumers to say what natural foods actually are. The same is true of foods construed to be of higher quality due to attributes of locality, tradition and so on. The one thing that is certain here is that, in the minds of consumers, quality embodies more than the measurable physical and chemical properties of food. While this is most obvious in rapidly rising consumption of certified organic foods (a system that successfully combines auditable production standards with the signification of less tangible characteristics such as naturalness), and the emergence of social movements around fair trade and slow foods, its implications for the mainstream food sector cannot be ignored.

With worldwide resistance to GM described as one of the fastest growing social movements in a generation' (Tokar, 2001, p. 315), it seems unlikely that the invisible penetration of unlabelled biotech products into the food marketplace will be tolerated. The results presented here suggest that some of the key determinants of long-term acceptance or rejection of biotech foods will be the extent to which the food industry is able to ensure that regulatory regimes (public and private) allow biotechnologies to be considered 'normal' and their ability to counter, in the minds of consumers, the arguments of social movement organisations that such foods are 'unnatural'. While confusion among consumers regarding the risks and benefits of biotechnology may be seen by some to justify the allocation of regulatory power to expert scientific institutions, such moves, in the past, have contributed to a crisis of trust in many such institutions and are inconsistent with the mission of retailers to use private regulatory regimes to build trust. Given that the key determinant of acceptance of biotechnology is concern for convenience in the procurement and preparation of foods, opportunities to increase the market penetration of biotech foods may coalesce around the development of genuine convenience benefits over their competitors. But this presents another area in which biotech foods potentially are vulnerable, as the opportunity to enhance convenience is just as open to the proponents of organic and other 'natural' foods as it is to the biotech industry.

\section{Conclusion}

In keeping with previous studies of consumer attitudes to biotechnology, this Australian study showed consumers to have mixed, but on average, less positive attitudes toward biotechnologies. It also showed, however, that the interactions between 
a small number of motivational and demographic variables can be used to explain much of the variability that is evident in the strength and direction of consumer dispositions towards biotechnology. The extent to which consumers were motivated to eat foods they considered natural had a very strong direct negative effect on their dispositions towards biotechnology, while the extent to which they were motivated to find foods that were convenient to purchase and prepare had a similarly strong, but positive, effect. Both these variables were influenced, in turn, by whether or not consumers took responsibility themselves for shopping for food for their households on a regular basis. Although this finding may appear contradictory, it is important to keep in mind the major effect of sex on almost all other variables including responsibility for shopping, natural foods and, to a lessor extent, acceptance of biotechnology directly. Finally, in a policy context, the results of the study support the cautionary approach being taken by most of the large supermarket chains: that is, providing consumers with what are construed to be 'natural' products, despite the 'convenience' that GE products might afford.

\section{References}

Barling, D., Lang, T., Caraher, M., 2002. Joined-up food policy? The trials of governance, public policy and the food system. Social Policy and Administration 36 (6), 556-574.

Black, J., 1998. Regulation as facilitation: negotiating the genetic revolution. Modern Law Review 61 (5), 621-660.

Burch, D., Lyons, K., Lawrence, G., 2001. What do we mean by "green"? Consumers, agriculture and the food industry. In: Lockie, S., Pritchard, B. (Eds.), Consuming Foods, Sustaining Environments. Australian Academic Press, Brisbane.

Cunningham, R., 2001. The Organic Consumer Profile: Not Only Who You Think It Is! Strategic Information Services Unit, Agriculture, Food and Rural Development, Alberta.

Decima Research, 1993. Final Report to the Canadian Institute of Biotechnology on Public Attitudes towards Biotechnology. Canadian Institution of Biotechnology, Ottawa.

De Vaus, D., 1991. Surveys in Social Research. Allen and Unwin, Sydney.

Florkowski, W.J., Halbrendt, C., Huang, C.L., Sterling, L., 1994. Socioeconomic determinants of attitudes toward bioengineered products. Review of Agricultural Economics 16, 125-132.

Frewer, L.J., Shepherd, R., 1995. Ethical concerns and risk perceptions associated with different applications of genetic engineering: interrelationships with the perceived need for regulation of the technology. Agriculture and Human Values 12 (1), 48-57.

FSA 2003. Date set for new GM Food Regulation. Food Standards Agency, UK. Available from: http:// www.foodstandards.gov.uk/news/newsarchive/new_reg.

Goodman, D., Redclift, M., 1991. Refashioning Nature: Food, Ecology and Culture. Routledge, London.

Grice, J., Lawrence, G., 2003. Consumer surveys of biotechnology: asking the questions until we get the answers we want OR Empowering the public to express their opinion, Paper presented at Agrifood Research Network Conference, Akaroa, New Zealand, 21-24 April 2003.

Hindmarsh, R., Lawrence, G., 2001. Bio-utopia: future natural. In: Hindmarsh, R., Lawrence, G. (Eds.), Altered Genes II: the Future? Scribe, Melbourne.

INRA, 1991. Opinions of Europeans on Biotechnology in 1991, Commission of the European Communities, Brussels.

INRA, 2000. Eurobarometer 52.1 The Europeans and Biotechnology. Available from: http:// www.europa.eu.int/comm/research/eurobarometer-en.pdf.

Kotz, S., Johnson, N.L., Read, C.B., 1982. Encyclopaedia of Statistical Sciences. Wiley and Sons, New York. 
Lang, T., Barling, D., Caraher, M., 2001. Food, social policy and the environment: towards a new model. Social Policy and Administration 35 (5), 538-558.

Lawrence, G., Norton, J., Vanclay, F., 2001. Gene technology, agri-food industries and consumers. In: Hindmarsh, R., Lawrence, G. (Eds.), Altered Genes II: the Future? Scribe, Melbourne.

Lemkow, L., 1993. Public attitudes to genetic engineering: some European perspectives, European Foundation for the Improvement of Living and Working Conditions, Luxembourg.

Levidow, L., Carr, S., 2000. Unsound science? Transatlantic regulatory disputes over GM crops. International Journal of Biotechnology 2 (1/2/3), 257-273.

Levidow, L., Tait, J., 1995. The greening of biotechnology: GMOs as environment-friendly products. In: Moser, I., Shiva, V. (Eds.), Biopolitics: A Feminist and Ecological Reader on Biotechnology. Zed Books, London.

Lindeman, M., Väänänen, M., 2000. Measurement of ethical food choice motives. Appetite 34, 55-59.

Lockie, S., 2002. "The invisible mouth": mobilizing "the consumer" in food production-consumption networks. Sociologia Ruralis 42 (4), 278-294.

Lockie, S., Salem, N., 2005. Governing consumption: mobilizing 'the consumer' within geneticallymodified and organic food networks. In: Higgins, V., Lawrence, G. (Eds.), Agricultural Governance. Routledge, London.

Lockie, S., Lyons, K., Lawrence, G., Mummery, K., 2002. Eating green: motivations behind organic food consumption in Australia. Sociologia Ruralis 42 (1), 20-37.

Lyons, K., Lockie, S., Lawrence, G., 2001. Consuming green: the symbolic construction of organic foods. Rural Society 11 (3), 197-210.

Marris, C., Wynne, B., Simmons, P., Weldon, S., 2001. Public Perceptions of Agricultural Biotechnologies in Europe, Final report of the PABE research project. Available from: http://www.lancs.ac.uk/depts/ ieppp/pabe/docs/pabe_finalreport.pdf.

Marsden, T., Flynn, A., Harrison, M., 2000. Consuming Interests: the Social Provision of Food. UCL Press, UK.

Mueller, R., 1996. Basic Principles of Structural Equation Modeling. Springer-Verlag, New York.

Murcott, A., 1999. The nation's diet and the policy contexts. In: Germov, J., Williams, L. (Eds.), A Sociology of Food and Nutrition: the Social Appetite. Oxford University Press, South Melbourne.

Newell, P., 2001. Biotechnology for the poor? Science as Culture 10 (2), 249-254.

Newell, P., 2002. Biotechnology and the Politics of Regulation, IDS Working Paper 146. Institute of Development Studies, Brighton.

Norton J., 1999. Science, Technology and the Risk society: Australian Consumers' Attitudes to Genetically-Engineered Foods, Unpublished Doctoral Thesis, Central Queensland University, Rockhampton.

Norton, J., 2001. Biotechnology to the rescue? Can genetic engineering secure a stable future for Australian agriculture? In: Lockie, S., Bourke, L. (Eds.), Rurality Bites: the Social and Environmental Transformation of Rural Australia. Pluto Press, Sydney.

Pearce, R., Hansson, M., 2000. Retailing and risk society: genetically modified foods. International Journal of Retail and Distribution Management 28 (11), 450-458.

Pew Initiative on Food and Biotechnology, 2004. Feeding the World: A Look at Biotechnology and World Hunger. Pew Initiative on Food and Biotechnology, Washington, DC.

Schweiger, T., 2001. Europe: hostile lands for GMOs. In: Tokar, B. (Ed.), Redesigning Life: the Worldwide Challenge to Genetic Engineering. McGill-Queen's University Press, Montreal and Kingston.

Steptoe, A., Pollard, T., Wardle, J., 1995. Development of a measure of the motives underlying the selection of food: The food choice questionnaire. Appetite 25, 267-284.

Tokar, B., 2001. The worldwide resistance to genetic engineering. In: Tokar, B. (Ed.), Redesigning Life: the Worldwide Challenge to Genetic Engineering. McGill-Queen's University Press, Montreal and Kingston.

Weeks, D., 1999. Promises and problems associated with agricultural biotechnology. In: Weeks, D., Segelken, J., Hardy, R. (Eds.), World Food Security and Sustainability: The Impacts of Biotechnology and Industrial Consolidation. National Agricultural Biotechnology Council, Ithaca, NY. 